\title{
Erratum: A flavanone from Baccharis retusa (Asteraceae) prevents elastase-induced emphysema in mice by regulating NF-KB, oxidative stress and metalloproteinases
}

Laura Taguchi ${ }^{1}$, Nathalia M. Pinheiro ${ }^{3}$, Clarice R. Olivo ${ }^{3}$, Alessandra Choqueta-Toledo ${ }^{3}$, Simone S. Grecco ${ }^{2}$, Fernanda D. T. Q. S. Lopes ${ }^{3}$, Luciana C. Caperuto ${ }^{1}$, Mílton A. Martins ${ }^{3}$, lolanda F. L. C. Tiberio ${ }^{3}$, Niels O. Câmara ${ }^{4}$, João Henrique G. Lago ${ }^{2}$ and Carla M. Prado ${ }^{1,3^{*}}$

\section{Erratum}

After publication of the original article [1] it came to the author's attention that FAPESP were not acknowledged as the agency who financed the study. The authors wish to thank the contribution of FAPESP.

\begin{abstract}
Author details
${ }^{1}$ Department of Biological Science, Universidade Federal de São Paulo, Rua Artur Riedel, 275 - Eldorado, Diadema, SP, Brazil. ${ }^{2}$ Department of Exact and Earth Sciences, Universidade Federal de São Paulo, Diadema, Brazil. ${ }^{3}$ Department of Medicine, Faculdade de Medicina da Universidade de São Paulo, São Paulo, Brazil. ${ }^{4}$ Department of Immunology, Biological Institute, Universidade de São Paulo, São Paulo, Brazil.
\end{abstract}

Received: 4 August 2015 Accepted: 4 August 2015

Published online: 17 September 2015

\section{Reference}

1. Taguchi L, Pinheiro NM, Olivo CR, Choqueta-Toledo A, Grecco SS, Lopes FDTQS, et al. A flavanone from Baccharis retusa (Asteraceae) prevents elastase-induced emphysema in mice by regulating NF-KB, oxidative stress and metalloproteinases. Respir Res. 2015;16:79.

\footnotetext{
* Correspondence: carla.prado@unifesp.br

The online version of the original article can be found under doi:10.1186/ s12931-015-0233-3.

'Department of Biological Science, Universidade Federal de São Paulo, Rua Artur Riedel, 275 - Eldorado, Diadema, SP, Brazil

${ }^{3}$ Department of Medicine, Faculdade de Medicina da Universidade de São

Paulo, São Paulo, Brazil
} 